\title{
Teachers' Perceptions Regarding Levels of Involvement in Decision Making in Selected Management Tasks in Secondary Schools in Machakos County, Kenya
}

\author{
${ }^{1,}$ Salome Loko Mutuku And ${ }^{2,}$ John Aluko Orodho \\ ${ }^{1,}$ Mrs. Salome Loko MUTUKU is a Doctorate student in the Department of Educational Management, Policy \\ and Curriculum Studies, School of Education, Kenyatta University, Kenya \\ ${ }^{2,}$ Prof. John Aluko ORODHO is an Associate Professor (specialist in Curriculum Studies, Research Methods \\ and Applied Statistics) in the Department of Educational Management, Policy and Curriculum Studies, School \\ of Education, Kenyatta University, Kenya
}

\begin{abstract}
The study examined teachers' perceptions regarding their levels of in decision making process in selected management tasks in secondary schools in Machakos County, Kenya. It was premised on Bridges (1968) model of shared decision making in schools which provides the administrator at any level in an organization with criteria to guide him or her in determining when and how teachers should be involved in decision making. The study adopted a descriptive survey research design. Thirty (30) teachers were selected from the study locale through purposive and stratified random sampling techniques to reflect type of school, gender and teaching experience. A questionnaires which was validated and subsequently subjected to split-half method with a reliability coefficient of $r=.89$ and an interview guide were used to collect data from sampled teachers. The data generated from questionnaires was analyzed using descriptive statistics in the form of frequencies and percentages while the qualitative data from interviews was analyzed thematically and displayed in narrative and direct quotes. The study revealed that teachers were involved in decision making processes only on restricted matters related to collection and checking of exercise books, methods of teaching, but rarely on matters related to student mentoring, procurement of learning materials and students behaviour management. It was recommended that the school mangers, especially the principal as the overall manager at the school level, should endeavour to provide enabling administrative and pedagogical environments that increase the operational autonomy of the teacher to be able to actively get involved in decision making processes that structure the various forces of the school, classroom and its environments to meet the students learning needs and enhance their overall performance. The programmes of teacher education at the universities and colleges of education should be reviewed to transcend the boundaries of content mastery and delivery to aspects of class management like inculcation of integrity, procurement procedures and behavior management, amongst others. [315 Words].
\end{abstract}

Key Words: decision-making, zone of acceptance, management task area, teacher, head teacher.

\section{Background Information}

\section{Introduction}

In almost all countries of the world today, developed and developing, the teacher is presumed to be the manager of his or her class (Oluwole, 2014). There is also an increasing recognition of the indispensability of effective classroom management in the enhancement of quality teaching and learning in schools (Oliver \& Reschly, 2007; Oluwole, 2014, Calderon \& Teresa, 2013; orodho, 2013; Waweru \& Orodho.2014). According to Oliver and Reschly (2007), there is a high correlation between a teacher's ability to organize classroom, manage the behaviour of his or her students and students' academic achievement. Conversely, poor classroom management can lead to negative educational outcomes (Oluwole, 2014).The teacher is ,therefore, expected to provide super classroom management effectiveness in his or her quest to enhance positive behaviour change in the students . Classroom management can be said to be that function of the school that concern the structuring of the four Ms of management, i.e. Men ( in generic terms), Money, materials, and Methods ( scientific and administrative ) by the class teacher in the most educative way possible to enhance learning (Calderon, 2013). Perhaps that's why Calderon (2013) highlights the functions performed by effective teachers as:

$>\quad$ Choosing, making and using the most effective instructional strategies;

$>\quad$ Designing classroom curricular that facilitates students learning;

$>\quad$ Considering the needs of the students collectively and individually and not just relying on prepared textbooks while designing the curriculum; and

$>\quad$ Implementing rules and regulations and imposing discipline actions. 
However, the concept of classroom management effectiveness in Kenya secondary schools is often subsumed in the overall management efforts of the principal which, according to Republic of Kenya (2013), and Alimi, Alabi, and Ehinola (2001) is the accounting officer of thee school and therefore to the exclusion of any other subordinate is praised or blamed for management effectiveness or ineffectiveness respectively in relation to the achievement of the school goal. Admittedly, some principals have some measures of influence to get their classroom teachers get things done properly in the classroom in order to ensure effective teaching and learning (Oluwole, 2014; Waweru \& Orodho, 2014). Writing on effective classroom management, Calderon and Teresa (2013) in agreement with Coggshall, Otti, Behrstock and Lasagna (2009) observe some classroom teachers are not effective in the discharge of their professional duties. Waweru and Orodho (2014) have also suggested that it's the principals' management techniques that translate directly to positive school outcomes, hence delegating the role of the teachers to the periphery (Waweru \&Orodho, 2014; Ampofo \& Orodho, 2014). This observation is disturbing particularly when the researchers formed their positions from the views expressed by some of the principals, the perceptions other fellow teachers. Therefore, since the principal is the overall school manager who is accountable to the teaching and learning process in a school, a research on teachers perceptions on their roles and actual involvement in decision process in schools from the perspective of the teachers themselves became relevant and germane. It is against this backdrop that this study on teachers' perceptions regarding levels of involvement in decision making in selected management tasks in secondary schools in Machakos County, Kenya was prompted.

\section{State of the Art Review}

Literature is prolific which indicates that although decision making as part and parcel of management requires a head teacher to work with and through individuals and groups, especially teachers to accomplish organizational goals or objectives this is hardly the case (Osguthorpe, 2008). According to McLaughlin \& Donoghene (1996), this could be attributed to the fact that the provision of quality basic school teachers has not been given priority and attention necessary to support the development of educational system of developing countries. Yet, all over the world, teachers in any society play a pivotal role in the development of the individual child. If teachers acquire the professional competence and attitudes that enable to actively perform their multiple tasks in the classroom, in the school and in the school community, teachers become the single most important contributing factor in ensuring quality educational prevision (Dave \& Rajput, 2000, Ampofo \& Orodho, 2014). Therefore, it is mandatory that teachers should be allowed to participate in decision making in given task areas if set educational goals and objectives have to be achieved. Involving teachers in the decision making process ensures that they are more likely to commit themselves to that decision than if individuals or small groups make the decisions on their behalf ( Ampofo \& Orodho,2014).

Writing on intellectual wisdom and intellectual teachers are called on by the times, Huisheng (2007) stresses that it is expedient to have competent and committed professionals in the teaching-learning enterprise, with high concern and dedication to the psychological, social and intellectual prosperity of future leaders the world over. Within this line of argument, it is apparent that teachers should be practitioners with high educational wisdom or solid knowledge base (Huisheng, 2007). By extension, therefore, it is clear that basic education teachers have a great responsibility of developing an individual holistically, and thus should actively participate in decision-making process in most educational matters. Thus, it is arguable that teachers who participate in decision making in a school organization are more likely to accept a decision and feel more responsible towards successful implementation. Participation in decision making results in teachers who are better informed and more knowledgeable about the decisions. The participants in the deliberation process are personally aware of the problems, the alternatives considered, as well as decision constraints, because they have been personally involved in confronting them while reaching the decision. Teachers who participate in decision making also develop rapport towards each other (Golstein, 2011). Through participation in decision making, teachers reveal their goals, ambitions, interests. They achieve better understanding which is useful in improving interpersonal communications.

In the words of MacCrimmon and Taylor (1976), teachers who participate in decision making are able to correct false assumptions and inaccuracies in the thinking of individuals. Involvement in decision making is a "people builder". Properly managed, teacher involvement in decision making becomes the means by which head teachers develop the skills and horizons of employees and increase their motivation. Greater efficiency is not the only reason for head teachers to involve teachers in decision making. Enrichment of workers jobs can have important results such as increasing their job satisfaction because their interests in the job increase along with responsibilities and challenges. MacCrimmon and Taylor (1976), justify this study by stating the importance of teacher participation in decision making. His study indicates that induction would tell us that teacher morale would be associated with the terms "decision making" from two points of reference. The first one is that teachers' morale would be higher if he had a fairly clear conception of who is responsible for making decisions. 
The second one is that teachers morale will also be aided if he believes he is capable of influencing the decisions which he believes legitimately belongs within his sphere of responsibility.

In a rejoinder, Daft and Becker (1978) notes that the human society from its most rudimentary form to the current sophisticated one has evolved through working together. People come together to discuss issues related to them, elect leaders and so on. Every group of organized people is a community by itself and has distinct features from one another. These features are not static but dynamic forces that require constant understanding, adjustment and development. The school as a community and the head teacher should harness these factors for the improvement and development of their institutions. Whenever decisions are made, they are aimed at achieving the goals of an organization. They may be made on the basis of past experience or intuition or simply to try and see if they will help solve organizational problems. In educational management, leaders at various levels of administration hierarchy make various decisions in their administrative activities. However, there is distinct relationship between the administrative level one occupies in the administrative hierarchy and the kind of decisions he or she has to make. Therefore, much of the work of an administrator involves making decisions because decision making and administration are almost synonymous. A major concern in the administration of education is, how can the process of participative decision making be implemented in education? An answer to this and other similar questions would go a long way towards clarifying the decision making component of the administrative process and clarifying to the needs for participatory decision making. It is important for educational managers at all levels of decision making to recognize the fact that nonprogrammed decisions (decisions in response to problems which are either novel or poorly defined like increasing the number students in the school when boarding and learning facilities are inadequate or buying a school bus when students do not have enough textbooks) are complex and involve a lot of risk - taking, and, therefore, enough time and other resources must be allowed for them. It is imperative that before non programmed decisions are made that environmental scanning which involves gathering as much information as possible and consultation be carefully undertaken. Thus, a concern of this study, teacher participation in decision making is of importance failure to which there may be serious repercussions. Organizations desire to achieve specific goals, and to respond to events in the environment in order to achieve these goals. It is difficult therefore to achieve the desired goals if the head teacher does not respond positively to the views expressed by his teachers who jointly work for the good of the school organization. Daft and Becker (1978:99) stress this view by stating that educational innovations tend to flow upward in the organization from teachers to administration. Most new ideas probably originate with organizations members who span the boundary between the organization and the technological environment, and teachers are the major spanning component for the educational environment (Daft and Becker, 1978:99). This means that the head teacher should practice consultative leadership which includes encouraging teachers to air their views in matters concerning their welfare and that of the work they do. Consultative leadership involves head teachers' explaining to the staff that as an administrator responsible for conducts of the school and its programme, one should make a decision but share his thinking with others. As an administrator one should carefully consider all suggestions and then make the necessary decision in light of considering the greatest good for the greatest number. This process involves amassing suggestions on the issues under discussion, analyzing views expressed and leaving the head teacher to decide on the basis of the suggestions from the teachers.

Knezevich (1975) further advances that prudent decision making is based on data that suggests alternative courses of action facilitate comparison and evaluation of alternative choices. The teachers build confidence in the head teacher and they become more responsible and innovative. The expectations held of a teacher therefore shoe how he/ she should act and the role will tell us roughly how he should act while occupying the position. The teacher has a wide area to deal with in the course of teaching. While discharging those important duties assigned to him/ her, he or she also performs tasks that could even be done by less qualified individuals. This involves keeping students files, maintaining teaching aids and preparing instruments for practicals. To fulfill his or her role; instructions, socialization and evaluation which are fundamental, the teacher must participate in decision making management task areas.

Adding her voice to this debate through a research carried out in Kenya, Karue (1980) Kenya asserts that the more a teacher believes in himself or herself to be a participant in decision making, the more he or she will perceive self as involved in innovative activity. The direct involvement in decision making in one's yield of endeavor releases dormant energy for productive use. When teachers participate actively in the process, their morale is boosted, and a cooperation atmosphere reigns in such an institution. The teacher in his/her endeavor to interpret the syllabus and simplify the materials that he/she has to teach involves making certain decisions. For example, to decide what extra books or materials he should use to supplement the text books suggested in the syllabus, he should do so without interference. This is because the teacher knows the ability of the pupils in his class, and his choice of the supplementary materials would very much depend on the knowledge of his pupils. Karue (1980) research project was concerned with those decisions that affect curriculum management, which is the priority of the teacher, and depends very much on the ingenuity and insight of a particular teacher. In her 
conclusion, she stated that if curriculum decisions are to be arrived at rationally, they must be based on the best evidence about society and its needs, evidence about the learners and how they learn, and evidence from the field of knowledge that learners are to study. Therefore, it is the teacher and the professionals that should be involved in decision making related to curriculum and instructional management (Karue, 1980). In this study, the importance of teacher participation in decision making in selected management task areas has been emphasized.

Heald and Moore (1970) made an observation that a policy that people have a hand in deciding receives more support than a policy which is imposed which will tend to receive greater scrutiny from those on whom it is imposed. Modern institutions of education emphasize freedom of participation and reciprocal cooperation. The head teacher has a task which has become taxing, challenging and at times overwhelming. Emphasis is now on freedom of participation and cooperation from teachers and less on dictatorship if the desired goals of the school have to be met. This means that the head teacher should involve teachers in making decisions especially when alternative courses of action are required. Making decisions in a cooperative manner, participative style of decision making are mandatory if the head teacher is to exercise a balanced administrative style. Teachers should be given a much bigger share in making those decisions that they have personal stake, interest and the expertise. Thus, the head teacher should involve them in decision making and seek to establish strategies for their participation through both formal and informal individual and group consultations.

Therefore, since decision making and administration are inseparable, a head teacher has a key task of managing it well because decisions made will affect the entire institution which the head teacher is responsible to govern. The processes of administration are carried out within specified areas of operation in a school setting. Specific activity areas (operational areas) define the tasks that an educational administrator performs in applying the processes. The teacher should be in a way be involved in decision making in these task areas because teachers feel responsible in implementing decisions they have participated in making. Administrative role tasks are categorized in different ways by different educational administrators. Campbell et al (1966) identified six operational task areas of a school administrator. They included finance and business management, curriculum and instruction; and, school community relations. Lipham and Hoer Jr. (1974), on the other hand, recognized five role task areas of the head teacher. They included: instructional program, staff personnel, financial and physical resources and school community relations. Bridge and Waters (1979) on the other hand identified the following areas: administration and school management, curriculum and supervision, pupil welfare and services, routine office and clerical work and school community activities. Nikolakis (1979) in his study of the role of the principal identified the following areas: school management, staff personnel, community relations and curriculum and instruction. Caweth (1983) only identified four key areas, which are critical to principal leadership and in which teachers should be involved in decision making. These areas included curriculum development, clinical supervision, and staff development and teacher evaluation. The various categories of the key role task areas of the head teacher show that there are no universally accepted categories of the roles which teachers should be involved in decision making. This situation is acknowledged by Lipham and Hoer Jr.(1974) who opine that even though principalship was a well established position in the field of education, there are still disagreements concerning the nature and boundaries of the major functional categories or tasks of principal roles. Miklos (1973) specified the tasks into student personnel, staff personnel, curriculum and instructional program, resources and facilities, financial affairs, community-institution relation and over all management which runs through all the other tasks. Therefore, common role tasks include; school management, curriculum and instruction, staff personnel, pupil personnel and school community relations. Taking into consideration the various operational management task areas of the secondary school head teacher in Kenya, the following role tasks areas of the secondary teacher are examined as areas in which he or she should be involved in decision making: curriculum planning and adaptation, classroom management, arrangement of instructional programme, general school organization and out of school activities.

In this study the following role task areas of the secondary school teachers are examined as areas in which the teacher should be involved in decision making. This include; curriculum management, classroom management and instructional programme. Curriculum management comprised of who makes decisions on the selection of text books, selection of teaching materials, on who decides who teaches which class, who decides on the selection of text books and who plans the curriculum for subjects. In the task area of classroom management, areas looked into were decisions on who goes as a class teacher to which class, who decides on the discipline of students in class, who decides on how often pupils books should be collected and checked, who decides on which method of evaluating student progress and the determiner of the method of presenting subject matter in class. Instructional programme was looked at according to the routine activities in this area that call for decisions to be made. This area mainly focused on who determines size of class, subject areas for students, promotion of students, makes decisions on allocation of money to departments for supplies and equipment, determines cut-off marks of admission, decides on the timetabling and determines subjects to be taught in the morning, mid-morning and afternoon. As study conducted by Simpkins and Friesen (1970) revealed that 
teachers perceived themselves as involved in decision making only in the area of classroom management; that is, they participate in decisions concerning teaching methodology, examinations, relationships with pupils and performance of instrumental tasks. In the teachers' views, decisions were made by other people and institutional bodies. Other studies conducted in educational institutions in Kenya (Njoka, 1985; Ndambuki, 1986) also emphasize that teacher' desire to shift from being overpowered by administrative decisions and confined to the classroom to being more involved in matters pertaining to curriculum and instruction as well as general organizational decisions. Effective teacher participation in decision making in schools is a form of participatory management. According to Mueller \& Gokturk (2010), the overall performance of a school can be improved through the active participation of teachers in the schools' decision making process. This is because teachers are key figures in the implementation of curriculum decisions in terms of what to teach, how to teach and who to teach. The entire school environment improves and meets its educational goals when teachers are actively involved in controlling their work environment (Pashiardis, 1994). Therefore any limitations on teachers' involvement in decision making should be addressed so that school goals and objectives are fully met.

In Kenya, effective decision making in schools is emphasized. According to Okumbe (1998), a lot of resources are wasted by educational institutions as a result of poor decision making. Thus, there is the need for educational manager to learn fundamental organizational decision making process so as to advance the effectiveness of teaching and learning. He also adds that teacher participation in decision making is important for maximizing output (Okumbe, 1998). Research conducted by Mualuko, Mukasa \& Achoka (2009) on teacher participation in decision making in Makueni District indicate that teachers desire greater involvement in decision making than is currently accorded to them. The educational Act of the laws of Kenya of 1980 assumes that BOG members and teachers are efficient in accounting, human resource management, and law and project management. However, Wanderi (2008) argues that the administration of most schools does not acknowledge that teachers possess these skills as businessmen who are ignorant of the basic concepts of human resource management, school management and public finance are left to run the schools. He recommends that teachers should be further trained in accounting, financial, planning and project management so that they can actively engage in school management (Wanderi, 2008). Teacher participation in decision making is therefore important as it results in higher performance of schools' in an increasingly competitive educational world (Mullins, 2005).

\section{Statement of the Problem and Justification}

Despite the growing body of literature which show that quality decisions accrue in organizations when those close to the point of implementation are actively involved in decision processes, the extent to which teachers are involved in this process is not yet clearly documented. Yet, it is arguable, that some benefits are expected to arise from capitalizing on the specialised knowledge or abilities of the participants and some from the increased commitment, which might flow in planning and decisional activities. It is this lack of clarity on a clear understanding of how teachers perceive they have been actively been involved in decision making that prompted this study. The justification of this study is that teacher's feel resented when they feel they have been made to act as robots or get told what they are supposed to do without having a voice in the decisions that concern them. Richardson (1973) supports this idea by stating that, there is mounting frustration among teachers who feel they lack any real voice in the process of decision making.

\section{Purpose and objectives of the paper}

The study examined teachers' perceptions regarding their levels of in decision making process in selected management tasks in secondary schools in Machakos County, Kenya. This paper had three fold objectives, namely to determine the extent to which teachers are involved in decision making processes in areas such as:

1. Curriculum management.

2. Classroom management.

3. Choice of instructional processes.

\section{Theoretical Framework}

According to Bridges (1968), a model for shared decision making in schools; zone of acceptance provides the administrator at any level in an organization with criteria to guide him/her in determining when and how he/she should involve teachers in decision making. He bases his findings from the Ohio State University LBDQ Studies (Leader Behavior Description Questionnaire) originally developed by Hemphill and Coons (1950). The Ohio study focused on leadership style of principals and the "zone of acceptance" of teachers, that is, the range of behavior within which subordinates are ready to accept the decisions made by their superiors. Therefore, on one hand some directives are clearly inacceptable and will not be obeyed, while on the other hand some decisions are highly acceptable and meet with high interest and anticipation. By using this study the head teacher can determine the extent at which he should involve teachers in decision making. Bridges (1968) 
postulates that (1) as the administrator involves teachers in making decisions located in their zone of acceptance, participation will be less effective and (2) as the administrator involves teachers in making decisions clearly located outside their zone of acceptance, participation will be more effective. The administrator will then determine which decisions fall inside and which fall outside the zone of acceptance. If teachers have a personal stake (high relevance) in the decision and have the knowledge to make a useful contribution (high expertise), then the decision clearly falls outside the zone of acceptance, and teachers' should be involved in the decision making process. If the issue is not relevant and it falls outside their sphere of competence, however, then the decision clearly falls within the zone of acceptance and involvement in decision making should be avoided. In addition to determining when teachers should be involved in decision making, the administrator must also decide the extent of involvement. The extent of involvement focuses on the four stages of decision making; the first one is to define the problem. The second one is to list the alternatives. The third one is to predict the consequences for alternatives, and the fourth one is to make the choices (Bridges, 1968).

\section{Research Methodology}

The study adopted a descriptive survey research design. A combination of purposive and stratified sampling technique was applied to select 15 out of 24 public secondary schools, 15 secondary schools constituting 7girls' secondary schools and 8 boys' secondary schools. From the sampled schools, 30 teachers were randomly selected from a total population of 284 teachers in Kathiani District, Machakos County, Kenya. Thus, a total sample size was thirty (30) teachers were selected from the study locale through purposive and stratified random sampling techniques to reflect type of school, gender and teaching experience to participate in the study.

The major instrument for data collection in this study was the questionnaire-Teacher Participation in Decision Making Descriptive Questionnaire that was developed and administered to respondents in the schools. This questionnaire was divided into two parts; section "A" was meant to determine the teachers' involvement in decision making in the given task areas while section "B" was meant to determine their opinion on decision making. The questionnaires were validated and subsequently subjected to split-half method with a reliability coefficient of $\mathrm{r}=.89$ was enough to declare them suitable for data collection. An interview guide was also used to collect qualitative data from sampled teachers to corroborate the data collected through questionnaires, as recommended by Orodho (2012). The data generated from questionnaires with the aid of the Statistical Package for Social Sciences (SPSS) Computer package version 20 were analyzed using descriptive statistics in the form of frequencies and percentages while the qualitative data from interviews was analyzed thematically and displayed in narrative and direct quotes.

\section{Curriculum management}

\section{Research Findings And Discussion}

Table 1 summarizes data on teacher participation in decision making in curriculum management. According to table 1, teachers are the main decision makers in this area with $80 \%$ of teachers making decisions related to the selection of books. This was not surprising because teachers are subject specialists thus are aware of textbooks which best cover the content. Slightly less than two thirds of the teachers reported that they were involved in making decisions regarding teaching materials as well as the choice of supplementary books to be purchased for teaching purposes. More than one third of the teachers felt they made some contribution on decisions on the total number of continuous assessment tests CAT the learners should sit for in a term.

Table 1: Teacher Participation in Decision Making in Curriculum Management

\begin{tabular}{|l|l|l|l|}
\hline Management Tasks & Principal/HT & Teacher & MoEST \\
\hline Selection of textbooks & 10 & 80 & 10 \\
Selection of teaching materials & 36.7 & 63.3 & - \\
Teachers for classes & 90 & 10 & - \\
Number of C.A.Ts & 60 & 40 & - \\
Supplementary books to be bought & 40 & 60 & - \\
Planning the curriculum for a particular subject & - & 10 & 90 \\
\hline
\end{tabular}

The information carried in Table 1 also indicates that a majority of the teachers constituting $90 \%$ felt that headteachers dominated decisions regarding assignment of teachers for the various classes. About two thirds of the teachers felt that school principals dominated decisions regarding the number of CAT to be taken by students. Slightly over one third of the teachers reported that principals dominated decision making regarding the selection of supplementary reading materials and the purchase of learning materials. The principal, as the overall manager at the school level, has the responsibility of delegating responsibility and to deciding on who teaches which class. 
Majority of the teachers, constituting $90 \%$ of the sample considered the decisions making touching on planning of curriculum to be offered in each subject to be a preserve of the Ministry of Education. Thus, it was expected that since the Ministry of Education Science and Technology (MOEST), which is the central body incharge of education in Kenya would logically dominate decision making related to planning of the curriculum for a particular subject. The Ministry is responsible for coming up with goals and objectives of education which are geared towards achieving the needs of our country. The task of the head teacher in curriculum management is mainly on the implementation and evaluation of the Kenya institute of Education syllabus.

\section{Classroom Management Processes}

Figure1 summarizes data on teacher participation in decision making in classroom management. According to the information carried in Figure 1, teacher reported that making decisions on classroom management, they dominated the collection and marking of students books.

\section{Figure 1: Teacher Participation in Decision Making in Classroom Management}
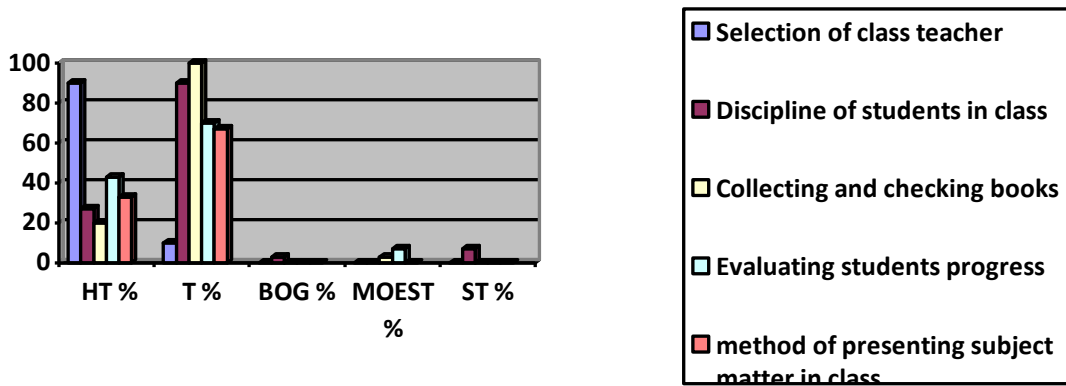

The second area where they made considerable impact was discipline of students in class. The third areas that received almost equal weight were evaluation of students' progress and decision on the method of presenting lesson. On the other hand, the teachers rated the assignment of the teacher to teach specific classes to be the preserve of the principal/ headteacher. The other area where the principal dominated was assisting teachers in deciding on teaching methods as well as evaluation of students' progress.

\section{Choice of instructional processes}

Figure 2 summarizes data on teacher participation in decision making in instructional programme. The information carried in Figure 2 indicates that a majority of the teachers, constituting $23.44 \%$ reported that they were mainly involved in decisions regarding the choice of teaching methods to be used for each subject taught in schools.

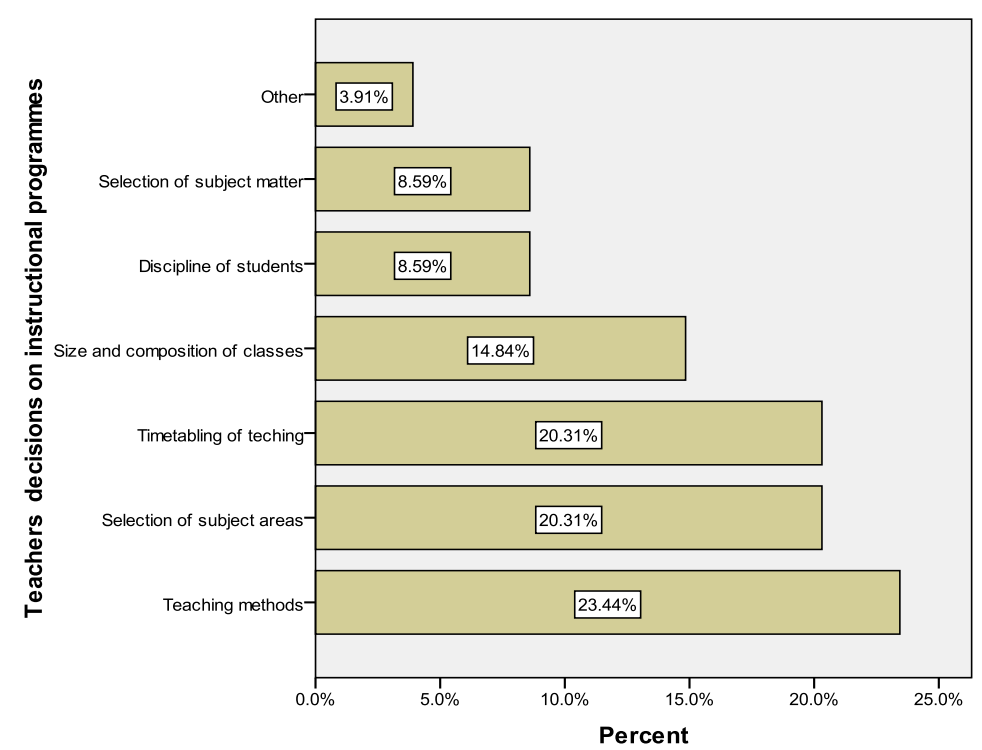

Figure 2: Teacher Participation in Decision Making in Instructional Programme 
An equal proportion of teachers, constituting $20.31 \%$ reported that they were involved in selection of subject areas to teach in each subject as well as timetabling of their subjects. The areas in which teachers reported minimal involvement in decision making as reported by $14.84 \%, 8.59 \%$ were composition and size of class, and student discipline, respectively. The implication here is that teachers had limited autonomy when it came to management of other areas of school functions such as student mentoring and procurement. This could be explained in terms of lack of enabling administrative and pedagogical environments that increase the operational autonomy of the teacher to be able to structure the various forces of classroom and its environment to meet the students learning needs. This also implies that the teachers have not been provided with appropriate knowledge and skills, together with better incentives to use their knowledge and skills for the benefit of the learners, as suggested by Good and Weaver, (2003).

\section{Conclusions And Recommendations}

From the findings obtained in this study it was found that teachers dominate in decision making in the curriculum management task area. In the classroom management, the teacher also played a dominant role in deciding how often pupils' books should be collected and checked and in determining the method of presenting subject matter in class. In the instructional programme management task area, teachers determine subject areas for individual students; as well as, determining the promotion of students. However, they perceived the role of the principal allocation of school funds for buying school supplies and equipment, determining the teaching load of teachers, determining policies to allocating the teaching load among the teachers, and in delegating responsibilities to teachers in the management task area of general school organization

On the strength of the foregoing findings and conclusions, it was recommended that:

First, the school principals as the overall managers at the school level should endeavour to provide enabling administrative and pedagogical environments that increase the operational autonomy of the teacher to be able to structure the various forces of classroom and its.

Secondly, there is need for greater involvement of teachers in decision making that goes beyond curriculum implementation and classroom management. This is because with more involvement of teachers there will be better quality decisions and improvements in the entire school administration and performance.

Third, teacher involvement in decision making should be encouraged as a way of improving collaborative skills, develop trust among those who participates, enhance inter- personal skills and increase job satisfaction. The head teacher should practice consultative leadership which includes encouraging teachers to air their views on matters concerning their welfare and that of the work they do.

Fourth, it is necessary to emphasize the concept of participative administration in secondary schools in Kenya especially during this era of strikes in schools and the abolition of caning in schools. This can be achieved through dissemination of ideas through Teachers training institutions. Serving teachers can be taught through in-service courses, seminars, meetings and conferences organized by teachers, head teachers, Kenya National Union of teachers (KNUT) and the MOEST.

Finally, greater incentives should be given to teachers so that they can be more willing to participate in some decisions that are thought to be in the head teachers' domain. This can boost efficiency in the general school organization.

\section{Acknowledgement}

I would like to extend my appreciation to Professor John Orodho of the department of Educational Management, Policy and Curriculum Studies, School of Education, Kenyatta University, Kenya, for his valuable guidance and academic mentorship which has enabled me accomplish the writing of this journal paper on time and successfully. To all my Phd colleagues, friends and family members who provided encouragement and support of whatever kind, your concern was not in vain. Glory and honour be to God for giving me good health and finances.

\section{References}

[1] Alimi,O.S.,Alabi, F.O. \& Eshinola,j.(2001).Teachers perception of principals leadership effectiveness in public and private secondary schools in Ondo State. Global Journal, USA (12) 22-27.

[2] Ampofo, S.Y., \& Orodho, A.J.(2014). Significance and delivery of teaching practice: Perceptions of Distance education teacher trainees of the University of Cape Coast, Ghana. International Journal of Recent Scientific Research.Vol.5. Issue 4.pp868-876, April, 2014.www.recentscientific.com

[3] Bridges. E M. \& Doyle W J. (1968). The Effects of Hierarchal differentiation on Group Productivity, Efficiency and Risk-Taking. Administrative Science Quarterly. Vol. 13(2): 305-319.

[4] Bridge .E.M \& Waters, P.A.N. (1979) 'The Actual and Desired Role of the Elementary Assistant Principal as Perceived by Elementary Principal, Assistant Principals and teachers in Indianapolis Public Schools.' Unpublished Ed. D dissertation. Indian University. Dissertation Abstracts International A, Vol 40, part 5.

[5] Calderon,.F.,\& Teresa ,F.(2013). Effective classroom management .17:3,34,

[6] Campbell, R.F. Corbally, J.E. and Nystrand, R.O (1969) Introduction to Education Administration, $4^{\text {th }}$ Edition, Massachusetts: Allyn and Bacon. 
[7] Caweth, G. (1983) 'Focusing Instructional Leadership on Improved Student Achievement,' Paper presented to American Association of school administrators, Anheim, California.

[8] Cogshall,J.,Ott, ,A.,Behrstock,E.,\& Lasagna ,.M.(2009). Supporting teacher effectiveness: The view from Generation Y,Nappervilee II and New York: Learning point. Retrieved http://www.learningorg/pdfs 19th May,2014.

[9] Daft, R.L. \& Becker, S.W. (1978). The Innovative Organization. New York: Elsevier.

[10] Dwivedi, R.S. (1988). Dynamics of Human Behaviour at Work. New Delhi: Oxford Publishing Ltd.

[11] Goldstein.(2011). Using pupil performance data for judging schools and teachers: Scope and limitations. London: University of London.

[12] Heald, J.E. \& S.A Moore (1968) The Teacher and Administrative Relations in School Systems.

[13] New York: The MacMillan Company.

[14] Hemphill, J. K. \& Coons, A. E. (1950). Development of the Leader Behavior Description Questionnaire. Columbus: Ohio State University, Bureau of Business Research.

[15] Karue, M.M. (1980). Decision Making in Primary Schools. Unpublished Masters Project, University of Nairobi.

[16] Knezevich J. Stephen (1975) Administration of Public Education.

[17] New York: Harper and Row Publishers.

[18] Lipham, J.M. \& Hoer Jr. J.G. (1974) Principalship: Foundation and Functions, New York: Harper and Row.

[19] MacCrimmon, K.R. \& Taylor, R.N. "Decision Making and Problem Solving," in M.D. Dunnette (ed.), (1976). Handbook of Industrial and Organizational Psychology. Chicago: Rand McNally.

[20] March, M.E. (1981). Control over Educational Decisions. Canadian Administrator. Vol. 21(3).

[21] Maritim, S. (1988). Teacher Participation in Decision Making: The Relationship between the Need to Participate and Status in Schools. Unpublished Project, Dalhousie University.

[22] Miklos, E. (1973) "Planning and Development; New Roles for The Principal," In School Administration for a Humanistic Era. No. 3 .

[23] Mualako, J., Simiyu, G,\& Achoka. S.K. (2009). Improving Decision Making in Schools through Teacher participation. Educational Research Review. Vol.4 (8). Masinde Muliro University of Technology, Kenya.

[24] Mueller, R.O. \& Gokturk, S. (2010). Multidimensionality of Teacher Participation in School Decision Making. Journal of Applied Sciences. Vol. 10 (14).

[25] Mullins, L.J. (2005). Management and Organisational Behaviour. Seventh edition prentice Hall.

[26] Muraya, P. (1981). Decision Making in Nairobi Primary Schools. Unpublished Master of Education Thesis, University of Nairobi.

[27] Ndambuki, J. (1986). Involvement of Teachers in Decision Making in Primary Teachers Colleges. Unpublished Masters of Education Thesis, Kenyatta University, Nairobi.

[28] Nikolakis, P.G.A (1979) 'A Study of the Role of the Assistant Principal as Perceived by Superintendents. Principals, Assistant Principals and teachers of middle schools,' Dissertation Abstract International, A. Vol 1 Part 5.

[29] Njoka, Z.G. (1985). Decision-making in Patterns in Selected Secondary Schools in Kirinyaga District. Published M.Ed. Project, Kenyatta University, Nairobi.

[30] Osguthorpe,R.D.(2008).On the reasons we want teachers of good disposition and moral character. Journal of Teacher Education. 59(4) pp288-299.

[31] Okumbe, J.A. (1998). Educational Management: Theory and Practice: Nairobi University press.

[32] Oliver,R.M,\& Richly, D.J.(2007).Effective classroom management : Teacher preparation and professional development culled from PDF, National Comprehensive Centre Teachers Quality ( May,2014).

[33] Oluwole,A.E.(2014). Principal's perception of teachers' classroom management effectiveness in public secondary schools in Ondo State Nigeria. International Journal of Development Research Vol.4.Issue3.pp399-402. March, 2014.www.journalijdr.com.

[34] Orodho, A. J. (2009). Elements of Education and Social Science Research Methods. Nairobi: Kanezja Publishers.

[35] Orodho, A. J. (2012a). Technique of Writing Research Proposals and Reports in Education

[36] and Social Sciences. Nairobi: Kanezja Publishers.

[37] Orodho, A. J. (2012b). Technique of Writing Research Proposals and Reports in Education and Social Sciences. Nairobi: Kanezja Publishers.

[38] Orodho, A. J. (2014). Financing Basic Education: What are the equity and quality implications of free primary education and free day secondary education policies in Kenya?. International Journal of Development Research. Vol.4.Issue 3,pp477-487, March,2014 www.journalijdr.com

[39] Pashiardis, P. (1994). Teacher Participation in Decision Making. International Journal of Educational Management. Vol. 8 (5).

[40] Richardson, E. (1973). The Teacher, the School and the Tasks of Management. London: Heinemann.

[41] Simpkins, W. \& Friesen, D. (1970). Teacher Participation in School Decision-Making. The Canadian Administrator. Vol. 8:13-16.

[42] Wanderi, C. (2008,). Management of Education in Kenya: Ministry has failed. The African

[43] Executive.

[44] Waweru,.N.P \& Orodho,A.J.(2014).Management practices and students academic performance in national examinations in public secondary schools in Kiambu County, Kenya. International Journal of Recent Scientific Research. Vol.5,Issue2,pp472-479 9 February,2014). www.recentscientifi.com . 